\title{
Desirability of Regulating Political Parties
}

\section{Gary Johns}

A ustralia's major political parties have generally been held to be private associations of political activists who freely determine their own activities. As such, they should not be subjected to government regulation. The scrutiny of their behaviour is a matter for their members and the electorate should only assess the parties' public performance. However, and more recently, the parties have developed into professional machines with head offices and organisers, and they receive funds from the taxpayer and from sources other than their members. In these regards, the parties have a degree of freedom from the membership by way of professional advice and non-member sources of funds. Furthermore, the parties' status has changed to the point where their history ideological, a large membership presence in the electorate and self-supporting belies their current role. The present parties are brand names with a nominal membership presence in the electorate, where the market for political activism has shifted to interest groups and where they are heavily supported by the state. For example, Gary Gray (1997), the former national Secretary of the Australian Labor Party, estimates a third of all funds available to the ALP comes from taxpayers. The new status of registered political parties is semi-public. Ideally, then, they should be beholden to the public, both electorally and in a more direct proprietorial way, as well as to their membership. The issue is to decide the regulatory mix that would preserve free political association and satisfy the taxpayer's investment.

The way these questions are addressed depends on the extent to which the party system relies on public trust. For example, the British parties are subject to a minor degree of regulation and almost no scrutiny. This is because the argument that parties 'are an essential part of civic society and the state should be kept at a distance' (Seyd, 1988:204), has won the day. The sentiment was elegantly put in a report (Houghton, 1976:75) on public funding, 'we think it mistaken and possibly dangerous to suggest that any work can be required of a political party - by the State, by Parliament or by anyone other than its members'. Further, '(d)irect state aid would breach the established British constitutional practice that organisation for political ends is a strictly voluntary activity' (Houghton, 1976:78). It appears that British political life will remain 'based strongly on trust' (Oliver, 1997:543). Is Australian political life, specifically those parts run by the parties, based strongly on trust? Do the voters trust the competition between the parties as a sufficient form of regulation or do they require as well, scrutiny of the internal operations of the parties?

Gary Johns is a Senior Fellow at the Institute of Public Affairs and is a former minister in the Commonwealth Government 
There is a strong case to suggest that the still predominant feature of Australian electoral politics, loyalty to the major parties, depends on the electoral system of single-member electorates, compulsory preferential voting and public funding, all of which are props for the major parties. Each prop also tends to be a barrier to the successful entry of new parties and Independents. The desire to regulate Australia's political parties arises from the fact that the three major parties (Labor, Liberal and National) have formed every Commonwealth and state government since 1941. In other words, it is a response to an oligopoly. Minor parties, such as the Australian Democrats and Independents, are keen on regulation of the majors in the name of enhancing competition. The difficulty with this view is that the oligopoly may arise from a stable political climate and the electoral system, and not be amenable to a party regulation solution. Nevertheless, it has not stopped the calls for legislative regulation (JSCEM, 2000:177). A second source of support for regulation comes from the parties themselves. They have devised systems of financial support, public funding, and consequently are subject to scrutiny in the administration of those systems. A third source of support for scrutiny comes from party members seeking to resolve disputes by litigation. A fourth source comes from the Premier of Queensland, who, as an exercise in winning favour with the electorate, intends to legislate to have the Queensland Electoral Commission scrutinise preselection ballots.

Each of these sources suggests that competition between the parties alone constitutes insufficient scrutiny. Each implies a different form of regulation. Some relate to the expenditure of public funds for elections, others to the internal operations of the parties, particularly with respect to the selection of candidates. For example, Somes (1996:157) argues that the requirement to register parties that seek public campaign funds may change their status from private to public. The implication is that the parties' behaviour per se should be subject to scrutiny. On the other hand, Forbes (1996:11) cautions that registration 'govern[s] a single external affair between the Commonwealth and the party as a whole' implying that the behaviour of parties at large should not be subject to scrutiny.

The suggestion from the regulators is essentially to impose internal democracy on the parties, as some form of compensation for the perceived shortcomings in the competition between the parties. The view ignores the long history of self-regulation, which is a major and unseen task of political parties. For example, they spend a great deal of their time managing the contest between party members for preselection. A recent comprehensive study of the parties (Johns, 2001) suggests the management of their procedures appears orderly and mature, in-as-much-as they each hold regular forums within which rules are discussed, often based on investigations and reports that involve the opinion and sanction of members. Their machinery for deciding preselection contests and settling disputes is in some cases extraordinarily highly sophisticated, in others rudimentary, but in all cases suggest that the parties are able to manage the processes reasonably well and in the main fairly.

How much regulation is too much? Finding the appropriate type and degree of regulation and scrutiny of Australia's political parties lies in an analysis of three 
phenomena: the nature and extent of government assistance; changes in the propensity of members of private associations to assert their right to fair internal processes; and, in the judgement of party leaders as to electorate's sensitivity the to party behaviour. For each, aspects of the internal behaviour of the parties are becoming more public. Together, they constitute an increased level of regulation not necessarily warranted by the behaviour of parties and may be a response to a wider climate of distrust in political process (for a comprehensive analysis of this phenomenon see Nye, Zelikow and King, 1997). The parties, however, as the most visible vehicle for political activism, will reap their share of the urge by the public, the media and other political activists to know more about them.

\section{Taxpayer Assistance and Consequent Regulation}

The taxpayer assists political parties in various ways. These are not always distinguishable from those that assist non-party members of parliament, but as political parties, indeed the major parties, dominate parliament in Australia it is reasonable to regard the assistance as beneficial to the parties. Indeed, of the 703 members elected to the House of Representatives between 1941 and 1998, only seven were not nominees of a major political party (Department of the Parliamentary Library, 1999:586). ${ }^{1}$ Moreover, in the thirty-one Ministries formed during the period no member of parliament who was not a member of the major parties has ever been a part of the government. It is unlikely these parties, Labor and the Coalition, would devise legislation to assist members where they did not become the principal beneficiaries.

Based on party returns to the Australian Electoral Commission (AEC), Horvarth (1999:56) calculates that Federal election funding between 1994 and 1997 constituted 19 per cent and 15 per cent respectively of ALP and the Liberal Party of Australia declared receipts. The figures do not include other forms of state assistance. If those other forms of assistance were included Gary Gray's observation of ALP finances would likely be accurate and valid for the other parties. The primary form of assistance to parties that are registered with the AEC is public funding for election campaigns. Registered parties spent $\$ 33.5 \mathrm{~m}$ of public funds at the 1998 Federal election at $\$ 1.62$ per vote (AEC, 1998:App. 2) and millions more at state and territory elections. Reflecting their lack of votes, only $\$ 276,000$ was spent by Independents. This level of funding is so generous that the AEC concluded, 'following the 1996 federal election most of the major parties were able to retire debt. Or to put it another way, most of the major parties made a profit out of contesting the first federal election following the increase in public funding ... The positive cash flow effects of public funding on party finances continued into the 1998 federal election.' (AEC, 2000:18).

Another form of assistance is the benefits, apart from salaries, members of parliament receive in order to pursue their work. The total outlays in 1999-2000

1 Excludes those who resigned from their party while in parliament, and those who subsequently stood as an independent. 
for the provision and administration of Commonwealth parliamentarians' entitlements were estimated to be at least $\$ 354 \mathrm{~m}$ (Auditor-General, 2001:11). The difficulty with these entitlements is that members have to pursue a number of objectives. The money they expend on printing and travel for parliamentary and electorate purposes for example are not always easy to separate from party business. Moreover, the Auditor-General (2001:21) noted:

A number of reviews of the administration of Parliamentarians' entitlements have identified the need for clear guidance as to the definition of the terms 'parliamentary business', 'electorate business' and 'party business'... [G]iven the key role the terms play in determining Parliamentarians' eligibility for a number of otherwise largely unlimited entitlements, the transparency and accountability of the entitlements management framework would be improved by the provision of enhanced guidance to Parliamentarians on the activities likely to be considered to represent parliamentary, electorate and party business ... A particular need for greater clarity and certainty relates to the use of entitlements by Parliamentarians during periods of byelections and general elections.

A third area where parties may seek to use funds for party purposes is in the employment of staff. A recent case before the NSW Industrial Relations Commission, concerning a former staff member of a NSW state member of parliament provides an insight into the use made by members of their staff. The staff member is suing the NSW Speaker for compensation for a harsh and unfair employment contract. Part of the allegation is that she had been expected to gather names and ALP membership forms, while an unidentified third party who was neither an employee nor a volunteer - paid the membership dues. 'The consequence of this activity, called branch-stacking, was one that was clearly directed from [the member] to [the staffer].' (The Australian, 2001:2). Clearly, this is taxpayer assistance to a political party.

Another area where a party, in government, seeks to use public funds for electoral advantage is advertising. The Auditor-General reported expenditure on government advertising on the changes to the taxation system, the GST in particular, in the lead up to the 1998 election:

In contrast to some other jurisdictions, there are no Commonwealth guidelines or protocols on information and advertising campaigns which would inform members of the Parliament and the Government on the framework to be applied, covering matters such as distinguishing between government and party-political advertisements, the distribution of unsolicited material and conduct of campaigns in the lead up to an election ... $[\mathrm{H}]$ istory shows it is not uncommon for Government advertising to increase in the period immediately preceding an election (Auditor-General, 1998:para 25). 
Further, the audit noted:

As at 31 August 1998, the date the Community Education and Information Program [the advertising for the new tax system] formally ceased due to the caretaker convention, $\$ 14.9 \mathrm{~m}$ had been expended and committed on the Community Education and Information Program. (Auditor-General 1998:para 1.14).

While a party in government will continue to argue the right to inform the electorate of changes to the law and programs, Opposition will continue to criticise such expenditure as party-political right up until the time it is their turn to govern! Nevertheless, the opportunity for parties to sell their message at public expense provides a significant advantage over competitors and begs some form of regulation.

These four areas of expenditure are significant - they assist incumbents to retain their seats and given most incumbents are party members this is a considerable advantage to the parties. Nevertheless, the fact that the expenditures are on the public record and subject to audit indicates that the advantages that parties may derive from such expenditures are subject to a regime of scrutiny. Whether such scrutiny does more than legitimise the use of public funds for partypolitical purposes is open to debate. What is clear is that information about the sources and extent of assistance, including disclosure of donations is publicly available. Less clear is the means to distinguish the ability of parties to 'piggyback' party and electoral/parliamentary/government activities. If such distinctions are well managed, that is, where the public is well informed, it is reasonable to conclude that further regulation of the parties at large is not warranted.

\section{Member Agitation and Legal Scrutiny of Parties}

Another form of party scrutiny has emerged from the courts and involves members of political parties. This has arisen from a more general community trend to assert the rights of members of associations and to have disputes resolved by litigation. Whether it is an effective means of providing individual members with a voice and a remedy is problematic. In 1991, Mr Baldwin, a member of the Liberal Party of Queensland, claimed that he had been improperly excluded from the Selection Council process by the Division executive, and consequently had failed to win preselection for the federal seat of Moreton. He took the matter to court (Baldwin v Everingham, 1993). For the first time a judge distinguished the Cameron v Hogan (1934) High Court decision which had regarded parties as no more than voluntary associations and as such not within the jurisdiction of a court. The dispute was justiciable because the rules of the Liberal Party, although a voluntary association, were registered under the Commonwealth Electoral Act 1918 (the $A c t$ ). 'There is now a significant public interest in the enforcement of the rules of registered political parties' (Baldwin v Everingham, 1993:24). The 
decision of the party executive was held to be contrary to the party constitution, and consequently the selection process had miscarried. A new preselection took place. Baldwin did not stand however, so his was a pyrrhic victory.

A second case (Thornley $v$ Heffernan, 1995), involved the Liberal candidate for the Federal seat of Macquarie. In 1995, Jeanette Thornley was disendorsed and the party executive selected a new candidate without a plebiscite of local members, claiming that there was insufficient time to hold one because of the possibility of an imminent Federal election. Thornley claimed that this was unconstitutional and took the matter to court. The subsequent hearing determined that the executive acted within its powers and Thornley had to carry costs of \$70,000 (Thornley, 1998 and 1999).

Gerald Sullivan, Labor MLA for Wollongong, lost a preselection ballot in 1999 and took the NSW ALP to court (Sullivan v Della Bosca, 1999). Sullivan alleged the improper use of the N. 40 Rule whereby, under prescribed circumstances, the Labor Party NSW Administrative Committee may forgo a local plebiscite and, in combination with branch delegates, select a candidate. The judge found that the Administrative Committee's suspension of the ballot was within the rules and that although the credential protest should have succeeded, the delegate numbers would not have varied sufficiently to change the outcome of the ballot. Sullivan had to carry his costs for the action.

In July 2001, Bob Tucker, the Queensland Liberal Party candidate for Ryan, sought relief from the courts (Tucker $v$ Herron and Ors, 2001) because he faced a preselection panel consisting of essentially the executive and excluding the local membership. Tucker was successful, the court granted an injunction, with costs to Tucker, and directed the Division to hold a plebiscite in accordance with the party rules. Unfortunately for Tucker, he lost the subsequent preselection. One reason for the loss was the party rule that allowed one of his opponents to have new applicants for party membership constitute a majority of a party meeting. The not yet accepted members were able to vote to waive a rule allowing them to become eligible to vote in the plebiscite. Under other circumstances, there would be a period of qualification for eligibility to vote. Incompetent rule-making is a matter for the parties.

These few cases hardly inspire an aggrieved member to take a political party to court. In addition to the financial risk involved, the courts have only looked to the application of the rules. They have not looked to see if the rules have been applied fairly, or indeed if the rules themselves are fair. These are matters reserved for cases involving the interpretation of legislation or the decisions of public authorities, or indeed to contractual relations where equity is a consideration. For example, in the Thornley case, the discretion that the NSW Liberal Executive reserved for itself under the rules was extraordinarily wide. McLelland CJ found that public law principles such as the fair application of rules had no application to voluntary associations (Thornley $v$ Heffernan, 1995:9). This left him with a literal interpretation of the rules such that so long as the executive believed that there was insufficient time to hold a new vote it was within its powers to use the emergency procedures. The decision in fact entrenched a very 
broad power of the executive to disendorse a candidate and endorse its own without reference to the membership.

Indeed, the situation before Clarke v Australian Labor Party (1999) was not a major breakthrough in asserting the rights of members to fair dispute processes or democratic outcomes. The Clarke cases, however, have opened to public scrutiny the integrity of membership recruitment and of the processes afforded members for the resolution of disputes. The dispute arose over an attempt to defeat Ralph Clarke, a former deputy-leader of the South Australian Parliamentary Labor Party, at preselection. Clarke alleged that 70 new members in his area joined the party on 26 January 1999 but did not pay membership fees personally nor, when invited to, did they attend the local sub-branch. The same occurred in other parts of the South Australian Party. In all, 2,000 members were 'joined' on 26 January, which, in a party with a membership of just 3,500, was a veritable stacking spree. The cost of these memberships was $\$ 42,000$, which by extension means that 'the entire South Australian branch [division] could be purchased for less than $\$ 100,000$ ' (Clarke 1999). The question that arose was whether the struggle for power within the South Australian Labor Party was played out according to the rules of the party. The court found a number of serious deficiencies in the way in which those responsible for the administration of the party had handled the issues.

There are a number of outcomes from the Clarke victories. There were rule changes to ensure that members 'must earn their stripes' (Clarke, 1999) before being eligible to vote in a preselection. The policy behind the proposed rule changes is to encourage a more transparent process of membership recruitment and renewal. The effect may be to slow and regularise the battle for preselection through recruitment. There is also a more serious second matter, the protection of the integrity of association of the party. For example, an association that consists of a large number of people who are unaware of their membership, or who have that membership paid for by others, or who have joined without any apparent adherence or knowledge of the objectives of the association, will not instil a great deal of confidence that it is an association of free individuals. In such cases, the integrity of the association would be severely threatened. Unfortunately for Clarke, he lost the subsequent preselection, but the legal victories have alerted parties that they are vulnerable to court scrutiny in the application of their rules and to public scrutiny, indeed ridicule, on the integrity of their membership.

In the matter of public funds the regulation and scrutiny of parties is relatively straightforward. However, the knock-on effect of the acceptance of funds has been to expose the parties to the scrutiny of the courts. This scrutiny has not proved directly beneficial to individuals but has encouraged the parties to offer some verifiable means of dispute resolution within their rules.

\section{More Direct Forms of Regulation}

That scenario may well change if another, more direct form of regulation of parties succeeds. The Premier of Queensland has vowed to introduce legislation into the Queensland parliament to ensure that the Queensland Electoral 
Commission supervises preselection ballots for registered parties. The legislation was devised to respond to the crisis of confidence in the ALP caused by the conviction of three party members for electoral fraud, and the resignation of three Labor MPs and a number of party members for witnessing or enrolling voters falsely. These transgressions of public law occurred in pursuit of advantage in preselection contests. Justice Shepherdson, who conducted the Inquiry into electoral fraud for the Queensland Criminal Justice Commission, agreed with the Beattie view in his recommendations (Shepherdson, 2001:171). The legislation is in the tradition of the public supervision of trade union ballots. In the Commonwealth sphere for example, the Workplace Relations Act 1996 has specified since 1988 (and decades earlier in some circumstances) that, unless exempted, all elections for office in registered organisations, trade unions and employer bodies, must be conducted by the AEC.

The trouble is the Beattie and Shepherdson solution for the public scrutiny of private ballots will confirm a lack of trust in all parties. The Shepherdson analysis does not justify public intervention in internal ballots. The Premier's motivation to involve the Electoral Commission is to spread the blame and the shame of intervention to all parties. This, despite the fact that no other member of any other party has been found to breach public law. Moreover, few, other than members of the Australian Workers' Union faction of the ALP have been found to breach public law. A problem predominantly in one faction, in one party, which is itself a small component of events affecting the overall standing of parties in the electorate, becomes every party's problem.

The defrauding of the electoral roll by Labor entities was a response to a particular set of party rules. The fact that the measure of preselection eligibility was enrolment to vote in an election created an opening to win preselection by stacking the electorate through false enrolments. Such behaviour is not necessary, for example, in the Queensland Liberal Party where a voter in a preselection does not need to be on the roll in the relevant electorate. If the National Party opts for a non-electorate qualification for preselections, the ALP could end up as the only party whose preselections are supervised by the Commission. Perhaps that would be a fair outcome, given that only ALP members breached public law.

The Beattie proposals are almost as invasive as those proposed by the Australian Democrats. The Joint Standing Committee on Electoral Matters (JSCEM) report into the 1998 Federal Election (JSCEM, 2000) discussed matters that relate to the internal operations of parties as they affect preselection. In particular, the Committee noted the AEC's view that 'most political party constitutions are scant, and inadequately address the internal functioning of membership-based organisations' (JSCEM, 2000:160). In fact, many of the parties' constitutions are not 'scant' at all; a recent audit of the rules of the major parties indicates their complexity and sophistication (Johns, 2000:401ff). They may, however, not be adequate as guides to good democratic practice. The issue is, who should determine, if not the parties, what is good democratic practice? Indeed, it was the view of the Commission and agreed by the Committee that the Commission should not have the power to impose itself upon the internal 
operations of the parties or to impose a definition of what is a democratic structure. The Committee was satisfied that the current approach for registration, whereby the parties lodge their constitution, was adequate.

This is not the view of the Democrats who seek a regulatory regime similar to that for corporations. They argue that the common law has been inadequate as a form of scrutiny and that the Act does not address the internal rules and procedures of political parties. The Democrats want political parties to be required to lodge a constitution with the AEC that must contain certain minimal elements. Among other things, they want the Act to be amended to require standard items to be set out in a political party's constitution, in a similar manner to the Corporations Law requirements for the constitutions of Companies:

The key constitutional principles of political parties should include: the conditions and rules of membership of a Party; how office-bearers are preselected and elected; how preselection of political candidates is to be conducted; the processes that exist for dispute resolution; the processes that exist for changing the constitution. The relationship between the party machine and the membership requires better and more standardised regulatory, constitutional and selection procedures, which would enhance the relationship between the party hierarchy, office-bearers, employees, political representatives and the members. Specific regulatory oversight to include: scrutiny of the procedures for the preselection of candidates in the constitutions of parties to ensure they are democratic; all important ballot procedures within political parties to be overseen by the AEC to ensure proper electoral practices are adhered to (JSCEM, 2000:177).

The Democrats are particularly scathing of the 'scourge of branch-stacking and pre-selection abuse' and suggest that a 'Member or Senator who has won their seat through branch stacking or pre-selection abuse can be seen as morally corrupt' (JSCEM, 200:178). To counter the problem, they recommend Committee and AEC scrutiny of branch stacking and pre-selection abuses. In particular, they seek to use the public principle of 'one-vote, one-value', and further recommend that the Act be amended to ensure the principle of 'one-vote one-value' be a prerequisite of political party processes. They suggest that application of such a principle in political parties would mean that one member's vote would not count more than another's and may rid parties of 'undemocratic and manipulated preselections, delegate selections, or balloted matters' (JSCEM, 2000:179).

What is a democratic weight of balance between branch members and unions, a key issue in the ALP, or between local branch members and members in other districts, a key issue in the Liberal and National parties, or for each party, between members and the central executive? The Democrats, for example, have so few members that they often have no local branch structure in most districts. Is there a minimum number of members in a local district that would persuade the Democrats state executive to select the candidate by consulting only the locals? It may be possible to specify in the Act some of the basics of procedure and some 
elements of free association, such as the self-payment of a joining fee, but the balance or weight of votes is very difficult. The notion that the AEC should oversee 'important ballot procedures' is a very large step indeed, and certain to cement the view that the electorate does not trust the parties. Still, the fact that the discussion is abroad stems directly from some considerable weaknesses in the integrity of the association of some parties and follows closely the discussion of the public funding of parties. For example, a former Commonwealth Electoral Commissioner, Professor Colin Hughes, has suggested to the Committee that, where 'candidates [of parties] registered with the Australian Electoral Commission are to be chosen by membership votes, those elections should be conducted by the officers of the Australian Electoral Commission' (The Sydney Morning Herald, 2000).

The major political parties have legislated to ensure the scrutiny of the democratic process in the key voluntary associations in industrial relations. They have done so, it appears, to enhance the confidence of the community and members in the conduct of ballots. There can be few more important ballots than those which determine who is to carry the party label of a major Australian party. It is almost the only road to parliament. Why then would the parties not do the same for themselves? Clearly, the Democrats want the parties to be scrutinised by the courts using a highly prescriptive legislative model. Such a model would incur all of the debate not only about the freedom of the parties to govern their own associations, but also the issues about the measures of democracy. It is highly unlikely that the parties will agree to such an intrusive regime, though a government at some point, needing the support of the Democrats, may begin to allow further specification in the process of party registration.

\section{An Acceptable Remedy?}

An obvious way for the parties to escape the recent enhanced scrutiny of their operations is to reverse the acceptance of public funding. If they ceased to accept public funds, in essence to reprivatise, would the grounds for public access to their internal regimes be any less compelling? In the first instance, almost certainly so. Apart from the rudiments of complying with electoral procedures, nothing is required of the parties by way of legislation other than that arising from their registration for public funds. It is clear that some of the work of the parties public information and voter registration - have been taken over by the state through government advertising and compulsory voting. They no longer have to get out the vote; they do not even have to raise many of the funds that sustain them. The education system and the media have taken up their role of educating the electorate. The parties are performing less but being paid more from the public purse. They barely represent the old class system cleavages of the electorate. It is more likely that the electorate is squeezed into an old shoe, one that fits the electoral system rather than the electorate.

Nevertheless, entering the confines of essentially private organisations, albeit when they are playing a public role, is difficult. It is made easier because the 
parties produce legislation that delivers them considerable public benefit. The strict contract between the registered parties and the Commonwealth may only require a proper accounting for election expenses, but there may also exist an assumption that their candidates, specified under the Act and shown on the ballot paper, arrive under fair circumstances. A possible remedy recognises both the right of private association and the harm that public control of preselections (for example, primaries) can do to the organisational integrity of parties, but seeks greater public scrutiny of the internal affairs of party candidate selection.

Presently, the parties registered under the Act, only have to lodge a copy of their constitutions with the AEC. These documents are not available to the public. A reasonable compromise on the tension between the external scrutiny of parties and the maintenance of the privacy of association would be, as a condition of registration, to make the party constitutions available to the public. If the parties' rules were to be made available to the public so that voters may judge for themselves the fairness of the processes, the parties would, as far as their formal practices are concerned, be more likely to comply with basic democratic standards. Of the possible options open to Australia's major parties - reprivatise, introduce a highly prescriptive regime of external scrutiny, continue court scrutiny of disputes, or make public their rules as a condition of registration for public funds - the last two seem the most practical. It would enhance democratic practice, maintain the trust in parties and ensure their freedom of association, itself an important element of democracy in Australia.

\section{References}

Auditor-General (1998), Taxation Reform - Community Education and Information Program, Australian National Audit Office (Audit Report No. 12).

Auditor-General (2001), 2001-2002 Performance Report Parliamentarians' Entitlements: 1999-2000, Australian National Audit Office (Audit Report No. 5).

Australian Electoral Commission (1998), 'Election Funding Payments', Appendix 2 in Funding and Disclosure Report of the 1998 Federal Election, available at: http://www.aec.gov.au/pubs/reports/disclosure98/appendix2.htm

Australian Electoral Commission (2000), Submission to the Joint Standing Committee on Electoral Matters Inquiry into Electoral Funding and Disclosure, Canberra, 17 October 2000.

Baldwin v Everingham (1993) 1 QLDR 10, 24.

Cameron v Hogan (1934) 51 CLR 358.

Clarke v Australian Labor Party (SA Branch), Hurley and Ors and Brown (1999) SASC 365 and 415.

Clarke, R. (1999), Australia Labor Party, South Australia, 'Interview', 27 October.

Department of the Parliamentary Library (1999), Parliamentary Handbook of the Commonwealth of Australia, $28^{\text {th }}$ edition, Canberra. 
Forbes, J. (1996), 'Judicial Review of Political Parties', Research Paper 21, Department of Parliamentary Library, Commonwealth of Australia.

Gray, G. (1997), National Secretary, Australian Labor Party, 'Interview’, March.

Horvarth, S. (1999), The ALP and LPA are Evolving into Cartel Parties, Honours Thesis, Department of Government, University of Queensland.

Lord Houghton (1976), Report of the Committee on Financial Aid to Political Parties, HMSO, London.

Johns, G. (2000), 'Party Democracy: An Audit of Australian Parties', Australian Journal of Political Science 35(3):401-25.

Johns, G. (2001), A Study in Democracy: Candidate Selection for the Parliament of the Commonwealth of Australia, Doctoral Thesis, School of Political Science and International Studies, University of Queensland.

Joint Standing Committee on Electoral Matters (1997), Report of the Inquiry into the Role of the Australian Electoral Commission in Conducting Industrial Elections, Parliament of the Commonwealth of Australia.

Joint Standing Committee on Electoral Matters (2000), 1998 Federal Election, Parliament of the Commonwealth of Australia.

Nye, J., P. Zelikow and D. King (eds) (1997), Why People Don't Trust Government, Harvard University Press, Cambridge, Mass.

Oliver, D. (1997), 'Regulating the Conduct of MP's: The British Experience', Political Studies 45:539-58.

Seyd, P. (1998), 'In Praise of Party', Parliamentary Affairs 51(2):198-208.

Shepherdson, Justice (2001), The Shepherdson Inquiry: An Investigation into Electoral Fraud, Queensland Criminal Justice Commission, Brisbane.

Somes, T. (1996), 'The Legal Status of Political Parties', p. 157 in M. Simms (ed.), The Paradox of Parties, Allen and Unwin, Sydney.

Sullivan v Della Bosca (1999) NSWSC 136.

The Australian (2001), 4 September.

The Sydney Morning Herald (2000), 15 November.

Thornley and Heffernan CLS 1995 NSWSC EQ 150 and CLS 1995 NSWSC EQ 206.

Thornley, (1998 and 1999), 'Interview' in 1998 and early 1999.

Tucker v Herron and Others (2001), Supreme Court QLD 6735 of 2001.

The author gratefully acknowledges the helpful comments of two anonymous referees. 